\title{
Territorial Structure of the Tourist Market in the Context of Regional Competitiveness
}

\author{
Irina Yu. Shvets \\ Yuri Yu. Shvets \\ Yulia V. Evdokimova \\ Galina M. Kolpakova \\ Institute of Tourism and Hospitality (Branch) of the Moscow-Russian State University of Tourism and Service, \\ Moscow State industrial University, Russian Federation \\ Email: uaevdokimova@mail.ru
}

\section{Doi:10.5901/mjss.2015.v6n3s5p267}

\section{Abstract}

\begin{abstract}
The economy of the tourist market is formed and functions on the basis of the interdependence of the companies in the region, the activities of which are directly or indirectly linked to the economy of tourism as well as preservation of the ecological balance of natural resources and historical, religious objects within the recreational territories. The result of the regional economy is creating and sustaining of the competitive advantage and achieving a higher level of competitiveness of the entire tourism industry. Profiling of a region should be aimed at creating a highly advanced tourist center of an international level that will enable long-term economic development. The real content of the concept of tourism will be shaped in the course of the collision of these positive trends and negative results, and will largely depend on the overall situation in the country, but on the other hand, in many ways it will determine the economic situation in Russia. Different types of tourism activities correspond to relative tourist spaces, representing part of the social space combining a set of interrelated natural and socio-economic conditions used for the tourism industry. The size and composition of the internal organization of a tourist space has a hierarchical structure. This article analyzes the structure of the regional tourist market and its subjects as well as key approaches to the formation of the concept of regional tourism management. The article discusses also examines spatialregional clustering of tourist areas, the basic conditions for the creation of tourist clusters, and the principles of the establishment and management of tourist clusters.
\end{abstract}

Keywords: cluster, territory, tourism, management

\section{The Essence of Territorial Recreational System}

During the process of recreation, there are economic and non-economic events and phenomena that constitute the essence of a recreational activity that has developed as a result of the further deepening of the social division of labor. The gradual transition of society from life-support model to the model focused on meaningful pastime experiences, which is typical of the post-industrial countries and countries with the information structure of the economy, gives grounds to predict subsequent growth of recreational activities and strengthening the diversity of its functions. The inherent complexity of the internal structure of recreation as a result diversifies the recreational demands of the population, which are reflected in the territorial organization of recreational activities. The form of territorial organization of recreational activities defines the territorial recreational system. It is a holistic, dynamic system, whose durability and reliability shames the functionality of the unity of components: vacationers, natural and cultural resources, infrastructure, staff and administration. Preobrazhensky proposed an understanding of the recreational system as an objective and social formation, based on its functional nature. Accordingly, an object of study of recreational geography is the study of territorial recreation systems (Preobrazhensky, 1975; Preobrazhensky \& Vedenin, 1971; Preobrazhensky et al., 1984; Transfiguration, 1975).

Recreational geography examines human activity, which is sociological in nature. But along with this, recreational geography is defined as frontier science, "located" at the intersection of geography, economy, and culture. In domestic practice it is common to define three main approaches to the definition of the research problems: a) environmental approach (study of physical and geographical areas); b) activity-based approach (study of the nature and activities of people); c) subjective approach (studied people's perception and its features). 
Almost until the end of the 1980s, the territorial structure of recreation was defined as socio-geographical area, focused on the study of territorial recreation systems (Mironenko \& Eldar, 1987, 1998; Vendina, 1989). Since the late 1990s, and in the future subject of study of the territorial structure of recreation is the study of spatial patterns and features of human behavior during recreational activities (mainly quarterly and annual cycles) and placing of recreational facilities. In defining the research subject of recreational geography, it is very important to abandon the narrow focus on territorial recreation systems (Mironenko \& Eldar, 1998; Montejano, 1997).

In recent years, the more common approaches deny the predominant role of territorial recreation systems as the main object of study of science. In determining the object and subject of recreational geography, Nikolaenko (2000), for example, believes that initially the following theses should be considered: geographical knowledge is not universal; it is closely connected with its social and cultural education. Therefore, within each socio-cultural education develops its unique understanding of what is the object and subject of recreational geography; each socio-cultural education has a logic of its own evolution and reflection on its evolution. Therefore, recreational geography as a field of scientific knowledge can take place not in all types of education. This is not an indicator of development or underdevelopment of a socio-cultural education, but only an indicator of its needs in this area of knowledge as a recreational geography.

These two points are very important for the understanding of the relativity of the object and the subject of recreational geography. We need to avoid unfounded universality of the definition of the object and subject, when they appear a single and unchanging for all time and all cultures. Recreational geography is a very special case of reflection, which occurs only within a specific socio-cultural education, and all the features of recreational geography are determined by this. The presence or absence of the recreational geography, as well as concrete forms of its realization as a field of knowledge are determined by the internal and external problems that are solved by social and cultural formations in the course of their evolution.

At a certain level and stage of evolution in the socio-cultural education a need for recreational geography as an area of knowledge may emerge. The main area of research is being formulated, as well as the resultant highly volatile subject of study. All this takes place not in the abstract, but as part of the evolution of a socio-cultural education.

\subsection{Recreational space: the nature, size, and species}

The purpose of this article is to examine the economic entity, the nature and structure of the tourism market in the context of regional competitiveness. Various types of recreational activities correspond to appropriate recreational spaces, which are "... part of the social space combining a set of interrelated natural and socio-economic conditions that are used for recreation" (Dimitar, 1972, p. 6). The size and composition of the internal organization of recreational space has a hierarchical structure (Table 1).

Table 1. Taxometric system of recreational regions

\begin{tabular}{cll}
\hline Taxometric rank & Taxometric unit & Territory Size \\
\hline V & Recreational zone & Hundreds of thousands, tens of thousands square kilometers \\
\hline IV & Recreational region & Hundreds of thousands, tens of thousands square kilometers \\
\hline III & Recreational sub-region & Thousands, hundreds square kilometers \\
\hline II & Recreational micro-region & Hundreds square kilometers, thousands hectares \\
\hline I & Recreational item & Tens, hundreds hectares \\
\hline
\end{tabular}

Source: Dimiter, 1972

Scientists divide recreational space into organized and unorganized types (Lubimtseva, 2005; Mamutov et al., 1992). An organized recreational spaceis a space having an organized system of how to control conditions of recreational activities, the main purpose of which is improving its efficiency due to the presence of specific, local spaces of all sizes. An unorganized recreational space is a space in which the system of conditions for recreational activities is regulated by man to meet his personal needs.

\subsection{Factors, elements, and forms of territorial specialization in the field of tourism and recreation activities}

Association of enterprises within the boundaries of populated location forms a recreational item and determines its specialization (Lubimtseva, 2005). Territorial specialization aimed to fulfill a tourist recreational function is based on the 
existing competitive advantages of the territory: the presence and types of recreational resources, their compatibility; the level of development of the market, production infrastructure, the level of development related activities. Superiority in the structure of the cultural and historical resources forms the basis of forming a part of the tourist and excursion specialization element of the territorial structure in the territorial division of labor and natural and recreational - tourist and recreational or resort. Depending on the specialization and the elements of the territorial structure forms a concentration of tourist activities can be presented items centers, nodes, represented both discrete and areal forms (Table 2) (Lubimtseva, 2005).

Table 2. Territorial structure of the tourist market

\begin{tabular}{|c|c|c|c|c|c|}
\hline \multirow{2}{*}{$\begin{array}{l}\text { Elements of Territorial } \\
\text { Specialization of } \\
\text { Consumer Market }\end{array}$} & \multicolumn{3}{|c|}{ Elements of territorial specialization of market producer } & \multirow{2}{*}{\multicolumn{2}{|c|}{ Form of elements of territorial specialization }} \\
\hline & Intermediary & $\begin{array}{c}\text { Tourist and Excursion } \\
\text { Services }\end{array}$ & Resort Services & & \\
\hline Unit & Unit & Sightseeing Item & & Discrete & $\begin{array}{l}\text { Standard offer, narrow specialization, seasonality } \\
\text { up to } 10 \text { thous. pers. }\end{array}$ \\
\hline Center & Center & $\begin{array}{c}\text { Tourist-Excursion } \\
\text { Center }\end{array}$ & & Discrete & $\begin{array}{l}\text { Differentiated offer, narrow specialization, } \\
\text { seasonality, up to } 100 \text { thous. pers. }\end{array}$ \\
\hline \multirow[t]{4}{*}{ Node } & Node & $\begin{array}{c}\text { Tourism and } \\
\text { Recreation Site }\end{array}$ & Resort & $\begin{array}{c}\text { Discrete } \\
\text { Areal }\end{array}$ & $\begin{array}{l}\text { Differentiated and unique offer, smoothed } \\
\text { seasonality, over } 100 \text { thous. pers. }\end{array}$ \\
\hline & & & Resort area & Areal & $\begin{array}{l}\text { Narrow specialization, unique offer, smoothed } \\
\text { seasonality, up to } 10 \text { thous. pers. }\end{array}$ \\
\hline & & & Resort region & Areal & $\begin{array}{l}\text { Differentiated and unique offer, smoothed } \\
\text { seasonality, up to } 100 \text { thous. pers. }\end{array}$ \\
\hline & & & Resort zone & Areal & $\begin{array}{l}\text { Differentiated and unique offer, smoothed } \\
\text { seasonality, over } 100 \text { thous. pers. }\end{array}$ \\
\hline
\end{tabular}

\section{Tourist Region as a Competitive Subject of Recreational and Tourism Activities}

The World Tourism Organization defines the tourist region as an area, which has a large network of specialized facilities and services necessary for the organization of leisure, learning or health improvement, which are sold to tourists or tourist group of service providers (Sustainable tourism development, 2003). From this definition, it follows that the tourist region is the goal of travel, tourism product, and competitive subject. The strategic goal of the region as a competitive unit is to ensure competitiveness in the long term. Competitiveness of regional tourism market depends on several factors: the socio-economic system of tourism policy, the public interest and the interests of the business population, the state of internal and external demand, the availability and status of resources, ecological system (Castellani \& Sala, 2010; Hunter, 1997; Ko, 2005; Le Moigne, 1990).

The tourism industry is integrated into the economy of the region through cooperative relations, social, market, communication and technical infrastructure, based on the interaction of market forces of supply and demand, adjusted the government's economic policy, and is based on regional resources: natural climatic, geographic, ecological, cultural and historical, infrastructure (human, financial, information, technology, organizational and economic).

One unique characteristic of tourism is that tourist services for the end user is represented as a chain of services (lodging, food, transportation, health care, entertainment and others.), which implies a large number of market participants, and the user sees the value of tourist services in terms of its complexity, projects their impressions of the services consumed as a whole on the region as a whole. Due to the large number of subjects of the tourist market and multi-level, the activities of market participants are often not coordinated, resulting in a decline in the value of the tourist product to the consumer, and thus reduction of the attractiveness of the region, the degree of competitiveness, and consumer refusal to make a trip to this tourist region.

The level of development of tourism in the region and the degree of its competitiveness has a direct impact on the level of development and competitiveness of tourism in the region. Characteristic of this influence is presented in the Concept of sustainable development of tourism, developed by the World Tourism Organization (Starovoitova, 2002). The concept considers the influence of the tourist complex, as a functional-territorial system, on the development of the region in several areas.

First, the direct impact: the cost of tourists turn into the income of tourist business entities, which enables the development of reproductive processes, both at the level of tourist enterprises and enterprises in the region included in the cooperative ties, creating a new tourism product and selling it. The second influence is indirect, which can be represented as a dependency: as a result of economic activity tourist destination for business entities pay taxes, some of which are transferred to the budget of the region, directed its development. These funds are the proceeds of companies 
providing tourist activities, taxes, with activities, which, in part is transferred to the budget of the region, which enables the development of expanded reproduction process at the regional level, expressed as a multiplier effect. The third impact is more social in nature. Advanced nature of reproductive processes in the tourist region leads to the creation of new jobs, the growth of household income, and thus, there is a trend of improving the quality of life in the region.

\subsection{The horizontal and vertical integration of tourist market participants as a factor of competitiveness growth of tourism in the region}

Expanded definition of the region as a vertical (industry) and horizontal (cross-sectoral) integration of functional and territorial systems can form a methodological basis of studying the tourism industry. The subject of analysis is the tourist system, within which operate tourist enterprises, organizations and institutions of different forms of ownership and management that use natural, therapeutic, educational and other resources to provide the target consumers and recreational services for profit.

Integration processes between participants of the tourism market are observed both in the horizontal and vertical levels. Horizontal integration is formed as a partnership between the companies that create and promote tourism product, forming an offer of tourist products respectively specialization offers local markets and the needs of different levels and segments of the market demand. The connection between the elements of the market supply and demand, and within the market itself offers tourist product, is based on market and communication and technical infrastructure (financial, marketing, transportation, communication, technical and other types).

The intensity of horizontal integration links--reproduction, distribution, management, backward, forward and others-depends on the presence and structure of the competitive advantages of tourism in the region and the intensity of the demand for tourism product of the region. Based on that, the scope of activities of the regional tourism market and specialization is determined. Vertical connections of companies, organizations of the tourist market with the other components of the complex socio-geographical areas: material production, non-production sphere, civil society organizations, government agencies, local communities, are formed on the basis of participation in the territorial division of labor and specialization.

\subsection{Maximum satisfaction of recreational needs of tourists as the most important factor in increasing the competitiveness of the regional tourism market}

Due to the fact that the demand for tourism product is elastic, the regional tourism market is influenced by two markets: the market demand and market supply and the influence of the first prevails. This creates conditions for the complexity of tourist and recreational functions, increasing its territorial concentration and specialization and leading to complication of the hierarchical structure of the regional tourism market.

To enhance the competitiveness of the regional tourism market in the long run its development should be directed to the creation of conditions to meet the needs of consumers. Compared with nature-centered models of the tourism system, where the development of recreational resources tied for first place, the human-centric models claim that tourism development should be focused on the needs of the person (Nikolaenko, 2000; Efremov, 2002).

V. S. Preobrazhensky, while analyzing the basic model of recreational system, indicates a key role of the person as a tourist center subsystem, noting that the state and properties of all the other subsystems depend on the requirements of the central subsystem, and the objective function is defined as a recreational system maximum possible satisfaction recreational needs of the person (Chodorow \& Nemolyaeva, 1985). Formation of mass tourism in our country in the postwar period is extremely fast, by the inclusion of new recreational resources and territories, but it is accompanied by exceptionally low logistics and quality of service.

By the end of the 1980s, a conflict emerged due to the inability to meet the recreational needs of the entire population while maintaining low, including subsidized prices on vacation. V. S. Preobrazhensky analyzed two research approaches ("the needs of the" and "of resources") in addressing the optimization of recreation, including its territorial aspects, as a fundamental principle for the design considered the recreational needs, rather than recreational resources.

The changing socio-economic system in our country, the strengthening of the degree of competition, and the transition to intensive type of expanded reproduction are making human needs the key incentive for tourist activates. Tourist needs include the needs of expanded reproduction of the physical, emotional, mental, intellectual and spiritual powers of man (Berezhnaya, 2004; Starovoitova, 2002).

Identification and analysis of tourism needs to be seen as part of public (public good), group (individual reference groups), as well as personal needs. This approach makes it possible to more fully meet the needs of consumers at all 
levels, create the conditions for the emergence of the needs, interests and motives in acquiring the tourism product through market segmentation. Creating competitive motivational models, due to the nature of consumer behavior, should be based on the principle of management of interests, as conscious tourist needs and interests through the management as the basis of motivation (see. Fig. 1).

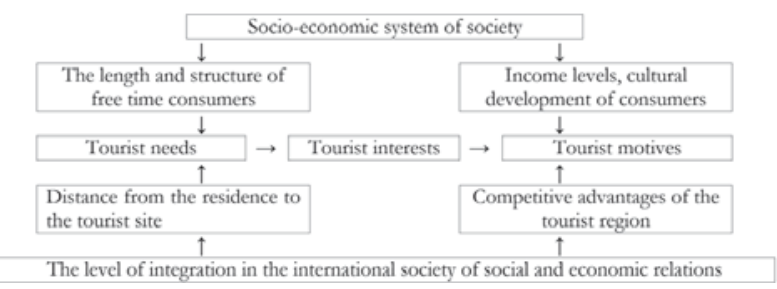

Figure 1. Scheme of links between tourist needs, interests, and motives of consumers and the factors affecting them

Tourist needs, interests, and motivations are affected by the level of socio-economic system through the level of development of society as a whole: the conditions for business development, health, education and culture, social security, technical and economic development of the system and the standard of living through the individual consumer: wages and working conditions, access to social benefits society. Cultural, historical and religious traditions, the level of socio-economic system have a great impact on the consumer preferences of society on its attitude to vacationing. The level of integration in the international society of social and economic relations is manifested through the open socioeconomic relations and accessibility for consumers to visit certain tourist sites.

Tourist needs are components of demand for tourism product. The demand for tourism product is determined by the needs of consumers, based on their ability to pay and the specific requirements for manufacturers of travel products and system existing tourism offerings. Competitive position in the tourist market requires constant generation of competitive advantages, anticipation, creating new needs.

2.3 Strengthening the relationship between needs, types of tourism activities and subjects of the tourist market as a growth factor for competitiveness of the tourist region

Based on the tourist needs, we can identify the following types of tourism activities undertaken by enterprises operating in the tourist market: therapeutic, sports and recreation, cultural, educational, scientific, educational, mediation, information, accommodation, food, transport, communications, trade (Table 3).

Table 3. The relationship between the needs, activities, and subjects of the tourist market

\begin{tabular}{|c|c|c|}
\hline Needs & Types of activities & The subjects of the tourist market \\
\hline $\begin{array}{l}\text { The need further reproduction of physical and } \\
\text { psychological force: the treatment, rehabilitation in } \\
\text { remission of the disease, preventive recovery }\end{array}$ & $\begin{array}{l}\text { Medical \& healing: health resort activities, } \\
\text { treatment and rehabilitation activities, medical } \\
\text { proven. activities }\end{array}$ & $\begin{array}{l}\text { Resorts with treatment, dispensaries, resort } \\
\text { polyclinics, balneology and mud baths, etc.. }\end{array}$ \\
\hline $\begin{array}{l}\text { The need for physical development, self-affirmation, } \\
\text { the reproduction of the physical and psychological } \\
\text { forces }\end{array}$ & $\begin{array}{l}\text { Sports and fitness: sports competitions, rallies, } \\
\text { marches }\end{array}$ & $\begin{array}{l}\text { Tourist centers, school of Olympic reserve, } \\
\text { stadiums, sports associations }\end{array}$ \\
\hline $\begin{array}{l}\text { The need for cultural development, in a change of } \\
\text { impressions, places, spiritual development }\end{array}$ & $\begin{array}{l}\text { Cultural sightseeing: historical, ethnographic, } \\
\text { environmental, green, religious, cultural and } \\
\text { entertainment nostalgic tourism }\end{array}$ & $\begin{array}{l}\text { Tour Desk, travel agents, theater, cinema, concert } \\
\text { halls, museums, ethnographic organizations, } \\
\text { historical, cultural, nature reserves }\end{array}$ \\
\hline Development needs, self-actualization & $\begin{array}{l}\text { Science and Education: Science, congress } \\
\text { tourism }\end{array}$ & Industry associations, educational institutions \\
\hline \multirow[t]{3}{*}{ Basic travel needs: } & Accommodation, & $\begin{array}{l}\text { Hotels, guest houses, resorts, campgrounds, } \\
\text { motels, dormitories }\end{array}$ \\
\hline & Nutrition & Restaurants, cafes, canteens, recreation \\
\hline & Transport & $\begin{array}{l}\text { Transport companies, own fleet bases } \\
\text { accommodation, tour agencies, tour operators }\end{array}$ \\
\hline $\begin{array}{l}\text { The need for communication, transmission and } \\
\text { receipt of information, material assets }\end{array}$ & Connection & $\begin{array}{l}\text { Telephone companies, the postal service, internet } \\
\text { service providers, mobile operators and mobile } \\
\text { communications, etc. }\end{array}$ \\
\hline $\begin{array}{l}\text { Need to maintain good memories, acquiring the } \\
\text { necessary things for your holiday }\end{array}$ & Business & Wholesale and retail trade \\
\hline $\begin{array}{l}\text { Need for sectoral cooperation, promotion of tourism } \\
\text { products }\end{array}$ & Mediation, Information & $\begin{array}{l}\text { Tour operators, travel agents, tourist information } \\
\text { centers, advertising agencies }\end{array}$ \\
\hline
\end{tabular}




\subsection{Availability and condition of tourism resources in the region as a factor in increasing the competitiveness of tourist} region

Quality satisfaction of the needs of the tourist directly depends on the availability and condition of tourism resources in the region. Tourist resources include natural and man-made objects, suitable for use in tourism. Tourist resources also include: direct: a) natural: landscape-climatic (beach, climate), natural landscapes, natural healing and hydro (balneology, mud-bath), b) cultural-historical; indirect: infrastructure (human, financial, information), material-technical base, enterprises of market infrastructure, the region's infrastructure, organizational and economic (legal, organizational and managerial). By natural resource recreation we mean recreational, but at the same time in some classifications of recreational resources, we see identity recreational tourism resources, "... natural, natural-technical and socio-economic geo-systems and their components, which can be used in existing technical and material resources for the organization recreational facilities" (Berezhnaya, 2004, p.11.).

In accordance with considering the classification of tourism resources, we can distinguish two groups of tourist activities: the first group: the activities carried out by enterprises, institutions that operate in the tourist market, and aims to provide tourism services based on direct use of resources; the second group: activities aimed at creating conditions for tourist activity, based on the use of indirect tourism resources.

Between the demand for tourism product (based on travel needs and income consumers) and the availability of, condition of the tourism resources in the region, there is a direct relationship, expressed in the formation of the elements of the tourism market. Unique tourism resources have limited distribution, which affects the local part of the tourist market (paragraph sightseeing, excursion center, tourist and recreational site), its elements forming its activities on the basis of these resources. Most often, these resources include cultural and historical resources. Common, the same type of tourism resources (natural tourism resources) are more accessible to more members of the tourist market, which involves the creation of larger structures tourism market (resort, resort area, district, and region).

Thus, the operation of the tourism market is based on the interdependence of the market and the consumer market products based on existing tourism resources (Fig. 2).

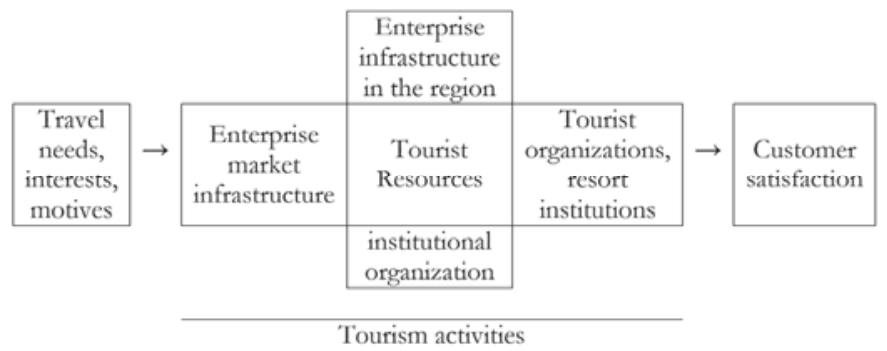

Figure 2. Scheme of interdependencies between markets consumers, manufacturers, and tourist resources of regional tourist market

The structural elements of the markets of consumer and producer, are in constant interaction, and they create new market segments and expand opportunities for existing segments. Base geospatial form regional tourism market is a linear network, which reproduces the spatial relationships of elements markets consumer and producer connected enterprises and transport infrastructure. Various travel needs are transformed into kinds of consumer demand.

Accordingly, the types of consumer demand form the segments of the consumer market, which are reflected in the territorial specialization that allows you to emphasize diversity of territorial structures of the regional tourism market. Each of these structures is based on the needs, interests and motivations of consumers and is influenced by certain factors. The characteristic feature of this form of territorial structure is the lack of hierarchy within the boundaries of this structure, resolution, selectivity.

This structure is more relevant to the local tourism market segments represented by unique (rare, geographically remote) tourist resources. The formation and functioning of this structure also indicates a low degree of competition, the immaturity of the market. Tourist regions having more common tourist resources having a high degree of competition, cooperation in the market, development of market relations, characterized by participation in an integrated spatial structures. The characteristic feature of this form of territorial structures include integrity, continuity, differentiation, multilevel, as structure elements belong to different hierarchical levels, have direct access to other functional levels. 


\section{Evaluation of the Competitiveness of the Tourist Regions}

Improving the competitiveness of regional tourist market associated with the optimization of spatial relations, must be first aimed at creating conditions for accessibility, diversity of tourist services for consumers, improving their quality by reducing the monetary and non-monetary costs for consumers. Second, tit must aim to create favorable framework conditions for the existence and development of institutional structures in relation to the overall economy, the tourism economy in the region in particular. Third, it must aim at improving the economic efficiency of the manufacturer.

While, assessing of the competitiveness of specific regional markets, we can note a large number of approaches and criteria often do not give the full picture, able in the future to provide substantial support in the implementation of the analysis of rating indicators and develop a mechanism to optimize the situation. Thus, one of the most common criteria for assessing tourism markets of Russian regions are revenues from tourism activities, usually in the form of a specific factor. As a common approach, we can cite an example of the ratio of income from tourism to the regional budget revenues (Frolov, 2012).

To date, the evaluation approach should be based not so much on the integral indicator of gross income from tourism, but on the system of indicators related to the evaluation (Girnal \& Tolstoguzov, 2011):

- the total tourist flow and a number of factors that can affect its value;

- spatial distribution of tourists in the regions;

- the size of the basic and additional tourist expenditure;

- the share of tourist expenditure associated with the purchase of local production;

- tax and non-tax revenues in the local and regional budgets;

- the extent of unaccounted supply of tourist services;

- basic and seasonal employment.

The World Economic Forum Optimal leverages an optimal evaluation approach to tourist markets, which is based on wide variety of data from common sources of information received from international organizations and the views of leading experts in tourism. Evaluation of tourist markets is based on the analysis of factors of competitiveness of sectors of tourism and travel, with a detailed competitive advantages and disadvantages. It examines the relationship between the visa facilitation and economic growth; the impact of the tourism sector to create jobs; relationship of aviation and economic development, estimated natural and cultural resources, development of the business environment, the quality of transport infrastructure and so on (World economic forum, 2014).

This approach is appropriate in view of the fact that today, the tourist market features:

- basic and seasonal employment changes in the structure of the recreational needs, and against this background there is a rapid segmentation of the consumer market;

- carried out a rapid transition to a mixed economy of tourism has developed rapidly in tourism business sector, acting on the basis of economic relations and mechanisms;

- a transition to the use of natural resources and cultural heritage on the basis of economic relations.

\section{Conclusion}

The proposed concept of resort and recreation economy is based on the following principles: resort and recreation economy is formed and functions on the basis of the interdependence of the integrated companies in the region (tourism clusters), the activities of which are directly or indirectly linked to the economy of recreation; activities of the tourism cluster is based on creating value for customers and cluster members based on the competitive advantages of the region; preservation of the ecological balance of natural resources and the historical, religious objects in recreational areas; the creation of a two-level focal point, whose main objective is to control, coordination in the tourism cluster, and mediation, execution of marketing operations, organization of work, both at the state level as well as in private.

The result of regional economic development is to create and maintain competitive advantage and achieve a higher level of competitiveness of recreation. Profiling the region should be aimed at creating a highly developed recreational, commercial, and financial center of international importance, which will allow long-term economic development.

The real content of the concept of tourism is indicated in the course of the collision of these positive trends and negative results. The concepts of development change as a result of the pressure of contradictions that require rapid resolution, because they are backed by very specific interests of the people. 


\section{References}

Berezhnaya, I. (2004). The economic structure of the Autonomous Republic of Crimea in the region of the leaves. Lviv: IRI NASU.

Castellani, V., \& Sala, S. (2010). Sustainable Performance Index for Tourism Policy Development. Tourism Management, 31(6), 871880.

Chodorow, L. F., \& Nemolyaeva, M. E. (1985). International tourism: yesterday, today and tomorrow. Moscow: International relations.

Dimitar, S. (1972). Economics and organization of tourism. Moscow: Progress.

Efremov, A. V. (2002). Sustainable development of tourism industry of the Crimea. Simferopol: Tavria.

Frolov, A. V. (2012). Tourism, welcome and economy (statistical rating of Russian regions). Bulletin of the RIAT, 2-3 (5-6), 4-12.

Girnal, E. V., \& Tolstoguzov, O. V. (2011). Regional tourism market: problems of assessment and management. Modern problems of science and education, 6. [Online] Available: www.science-education.ru/100-5119 (March 26, 2015).

Hunter, C. (1997). Sustainable Tourism as an Adaptive Paradigm. Annals of Tourism Research, 24(4), 850 - 867.

Ko, T. G. (2005). Development of a Tourism Sustainability Assessment Procedure: a Conceptual Approach. Tourism Management, 26(3), 431-445.

Le Moigne, J. L. (1990). Tourism as a Sustainable Livelihood Strategy. Tourism Management, 30(1), 90-98.

Lubimtseva, O. O. (2005). The Market of tourist services (geopolitical aspects). Kyiv: Interpres.

Mamutov, V. K., Akmola, A. I., \& Dementieva, T. N. (1992). Recreation: socio-economic and legal aspects. Kiev: Naukova Dumka.

Mironenko, N. S., \& Eldar, E. M. (1987). New aspects of recreational geography. Bulletin of Moscow University. Series. Geography, 1 , 23-26.

Mironenko, N. S., \& Eldar, E. M. (1998). Humanitarian aspects of the study of recreational systems. Bulletin of Moscow University. Series Geography. No. 1, p. 22 - 27.

Montejano, H. M. (1997). The structure of the tourism market. Smolensk: SSU.

Nikolaenko, D. V. (2000). Evolution of development of the region and the formation of its recreational specialization. The state and prospects of development of tourism in the CIS. St. Petersburg: Institute of management and Economics.

Preobrazhensky, V. S. (1975). Physical and geographical aspects and problems of amusement. Geographical problems of the organization of tourism and recreation. Central Advertising and Information Bureau "Tourist", 1, 50-112.

Preobrazhensky, V. S., \& Vedenin, Y. A. (1971). Geography and Leisure: A study of the organization and planning of recreation areas. Moscow: Knowledge.

Preobrazhensky, V. S., Vedenin, Y. A., Zorin, I.V, \& Mukhina, L. I. (1984). Territorial recreational system as an object of study Geographical Sciences. Proceedings of the Academy of Sciences of the USSR. Geographical Series, 2, 34 - 42.

Starovoitova, O. A. (2002). Principles of systematization of the types of tourism. Ukraine's Economy, 5, 48-53.

Sustainable tourism development (2003). Madrid: World tourism organization. [Online] Available: www.world-tourizm.org/ruso. (March 26, 2015)

Transfiguration, V. S. (1975). The problem constructive geography: Theoretical foundations of recreational geography. Moscow: Publishing house "Nauka".

Vendina, O. (1989). A recreational environment and ways of optimization of the territorial organization of recreational activities. Theoretical problems of recreational geography. Moscow: EGAN..

World economic forum (2014). Travel and Tourism Competitiveness Index 2013. [Online] Available: http://www.weforum.org/(March 26, 2015). 